\title{
Disain Mitigasi Risiko Penularan Covid-19 di Lingkungan Industri Padat Karya dengan Metode FMEA
}

\author{
Mitigation Design of the Risk of Covid-19 Transmission \\ in a Labor-Intensive Industrial Environment \\ using the FMEA Method
}

\author{
Sugeng Santoso ${ }^{1}$, Septian Sugestyo Putro ${ }^{1}$, Ari Ana Fatmawati $1{ }^{1}$, Caesarani Gloria \\ Putri' ${ }^{1}$, Sa'dillah ${ }^{1}$
}

1)Prodi Magister Manajemen, Fakultas Pascasarjana, Universitas Mercu Buana, Jakarta, Indonesia

*Corresponding Email: ariana.aa66@gmail.com

\begin{abstract}
Abstrak
Indonesia telah mengonfirmasi kasus pertama penularan Covid-19 pada 2 Maret 2020, dan sejak saat itu penularan virus tersebut semakin meluas dan memunculkan episentrum baru. Episentrum tersebut selalu melibatkan kerumunan, tidak terkecuali pada area pabrik yang beroperasi dengan padat karya. Metode penelitian menggunakan kuantitatif-deskriptif. Perusahaan yang beroperasi dengan padat karya, membutuhkan keterlibatan tenaga manusia dalam jumlah besar. Dalam proses produksinya, jarak antara tenaga kerja satu dengan lainnya tidaklah berjauhan sehingga memperbesar risiko penularan. Kasus terbaru di bulan September 2020, 150 karyawan sebuah pabrik di kota Purbalingga dinyatakan positif terjangkit virus Covid-19. Diduga kuat penularan terjadi di area kerja melalui tenaga kerja yang tanpa gejala. Dengan terus terjadinya penularan Covid19 di area industri, artikel ini bertujuan untuk mengajukan proposal penerapan desain mitigasi risiko penularan Covid-19 pada industri padat karya dengan metode FMEA, yang mencangkup layout area kerja, arus pergerakan manusia di area pabrik, dan penerapan protokol kesehatan dengan harapan dapat membantu industri padat karya dalam menekan dan mencegah penularan Covid-19.

Kata Kunci: Covid-19, FMEA, Risk Management, Padat Karya, Industri.
\end{abstract}

\begin{abstract}
Indonesia has confirmed its first case of Covid-19 transmission on March 2, 2020 and since then the transmission of the virus has become more widespread and has created new epicenters. The epicenter always involves a crowd, including in labor-intensive factory areas. This research method uses quantitative-descriptive. Companies that operating labor-intensive require the involvement of large numbers of people. In the production process, the distance between workers is not far apart, thus increasing the risk of virus transmission. The latest case in September 2020, 150 employees of a factory in the city of Purbalingga tested positive for the Covid-19 virus. It is strongly suspected that transmission occurs in the work area through asymptomatic labor. With the continued occurrence of Covid-19 transmission in industrial areas, this article aims to submit a proposal for the application of a risk mitigation design for the risk of Covid-19 transmission in labor-intensive industries using the FMEA method, which includes the layout of the work area, the flow of human movement in the factory area, and the application of health protocols in the hope of helping labor-intensive industries in suppressing and preventing the transmission of Covid-19
\end{abstract}

Keywords: Covid-19, FMEA, Risk Management;,Labor intensive, Industry.

How to Cite: Santoso, S., Putro, S.S., Fatmawati., A.A., Putri., C.G. \& Sa'dillah. (2021). Disain Mitigasi Risiko Penularan Covid19 di Lingkungan Industri Padat Karya dengan Metode FMEA. JKBM (Jurnal Konsep Bisnis dan Manajemen). 7 (2): $149-166$ 
Santoso, S., Putro, S.S., Fatmawati., A.A., Putri., C.G. \& Sa'dillah. (2021). Disain Mitigasi Risiko Penularan Covid-19 ...

\section{PENDAHULUAN}

Dalam kegiatan sebuah industri padat karya, tenaga manusia merupakan salah satu yang menjadi input utama (Herman, 2014). Dalam menentukan standar operasional harus mengikuti tujuan organisasi (Simbolon \& Santoso, 2021). Keterlibatan tenaga manusia dalam proses produksi merupakan akibat dari belum tersedianya teknologi yang mampu menciptakan mesin atau alat bantu yang mampu meminimalisir keterlibatan manusia. Masih banyak ditemukan meskipun sebuah perusahaan telah mengadopsi teknologi mesin yang canggih, tetap membutuhkan tenaga kerja manusia dalam jumlah besar dalam menjalankan proses-proses lain yang tidak terjangkau oleh teknologi. Dengan utilisasi tenaga manusia dalam jumlah yang besar, proses produksi sebuah perusahaan akan sangat bergantung pada hal tersebut, terlebih industri padat karya memegang peranan penting dalam per- kembangan ekonomi suatu daerah. (Santoso, 2010)

Tuntutan kondisi ekonomi pada masa pandemi Covid-19 di Indonesia saat ini, menempatkan posisi industri yang menggunakan sistem padat karya di ujung tanduk, sehingga produksi tetap diberlangsungkan demi mempertahankan keberlangsungan bisnis. Namun faktanya tidak semua perusahaan padat karya cukup efektif dalam menerapkan protokol pencegahan penularan Covid-19 yang telah digaungkan pemerintah. Sehingga pabrik padat karya acap kali menjadi episentrum baru bagi penularan Covid-19, beberapa contoh kasus bahkan menyebabkan ribuan tenaga kerja tertular. Pada Tabel 1 dapat dilihat kumpulan artikel yang memberitakan kasus penularan di area pabrik, utamanya di pabrik padat karya.

Tabel 1 Kumpulan Artikel Berita Penularan Covid-19 dalam Area Pabrik

\begin{tabular}{clccc}
\hline No. & \multicolumn{1}{c}{ Jenis \& Daerah Industri } & Sumber Artikel & Tanggal Publikasi & $\begin{array}{c}\text { Jumlah Karyawan } \\
\text { Positif Covid-19 }\end{array}$ \\
\hline 1 & Pabrik Rokok, Purbalingga & kompas.com & 24-Sep-20 & 150 \\
\hline 2 & Pabrik Elektronik, Cikarang & kompas.com & 27-Aug-20 & 242 \\
\hline 3 & $\begin{array}{l}\text { Pabrik Assembly Elektronik, } \\
\text { Cikarang }\end{array}$ & sindonews.com & 08-Oct-20 & 1381 \\
\hline 4 & Pabrik Sparepart, Cikarang & kompas.com & 31-Aug-20 & 88 \\
\hline 5 & Pabrik Rokok, Surabaya & kompas.com & 09-May-20 & 77 \\
\hline 6 & Pabrik Rokok, Paiton & kompas.com & 21-Aug-20 & 42 \\
\hline 7 & Pabrik Rokok, Sumenep & harianmerahputih.id & 27-Sep-20 & 94 \\
\hline
\end{tabular}

Sumber: Hasil Olahan Penulis, 2021

Dengan terus terjadinya kasus penularan di area pabrik padat karya sejak Indonesia menyatakan kasus pertamanya di 2 Maret 2020, diperlukan adanya sebuah sistem desain mitigasi pencegahan penularan Covid-19 di area pabrik padat karya. Artikel ini bertujuan untuk mengajukan proposal penerapan desain mitigasi risiko penularan Covid-19 pada industri padat karya dengan metode FMEA, yang mencangkup layout area kerja, arus pergerakan manusia di area pabrik, dan penerapan protokol kesehatan dengan harapan dapat membantu industri padat karya dalam menekan dan mencegah penularan Covid19.

Protokol Covid-19 untuk kawasan perindustrian diatur dalam (Menteri Perindustrian 
Republik Indonesia, 2020) Surat Edaran Menteri Perindustrian Nomor 4 tahun 2020 tentang Pelaksanaan Operasional Pabrik dalam Masa Kedaruratan Kesehatan Masyarakat Corona Virus Disease 2019, berikut merupakan rangkuman dari Surat Edaran Menteri Perindustrian tersebut di atas :

1. Bagi Pelaku Usaha

a. Menyediakan fasilitas screening awal kepada pekerja sebelum memasuki area pabrik maupun pergantian shift.

b. Melakukan pergantian Shift

c. Melarang pekerja yang berada dalam kondisi tidak sehat untuk memasuki kegiatan perusahaan.

d. Memastikan pekerja yang tidak sehat dan/atau memiliki riwayat perjalanan dari negara atau zona/kota dengan transmisi lokal Covid-19 dalam empat belas hari terakhir agar tidak memasuki area pabrik.

e. Memastikan lingkungan kerja memiliki sirkulasi udara yang baik.

f. Menyediakan suplemen dan makanan yang bergizi untuk seluruh pekerja.

g. Melakukan pembatasan jumlah pekerja saat penggunaan fasilitas umum, seperti tempat ibadah, kantin serta toilet.

2. Bagi Karyawan

a. Memakai masker serta ditambah sarung tangan selama berada di area pabrik.

b. Menjaga jarak minimal satu meter (social/physical distancing) dan dilarang berkelompok pada saat jam istirahat.

c. Dilarang berjabat tangan dengan sesama pekerja atau orang lain.
Peran pemerintah daerah untuk meningkatkan protokol Covid-19, dengan membuat peraturan dan melakukan pengawasan terhadap sektor perindustrian juga diharapkan dapat meningkatkan kesadaran industri akan bahayanya pandemi ini serta dapat mengurangi penyebaran virus Covid-19 (Deni \& Riswanto, 2019).

Salah satu sektor yang memiliki peran penting dalam pertumbuhan ekonomi industri di Indonesia adalah industri padat karya.

Untuk dapat memenuhi tuntutan produktivitas pada industri, para tenaga kerja dituntut untuk bekerja minimal 7-8 jam dalam setiap hari (Menteri Tenaga Kerja dan Transmigrasi, 2014). Namun, pengaruh tekanan dan tuntutan produksi di dunia industri dapat menyebabkan dampak negatif secara psikologis yang dapat mengurangi kesejahterahan para pekerja. Salah satu dampak negatif yang timbul adalah meningkatnya penularan Covid 19 di lingkungan industri.

Hal tersebut terjadi karena ketidaknyamanan pada lingkungan kerja industri berupa keterbatasan interaksi pekerja di dalam ruangan dengan lingkungan alami dalam jangka waktu yang panjang. Kurangnya interaksi dengan lingkungan sosial dalam jangka waktu yang panjang dapat menyebabkan konsekuensi psikologis yang negatif bagi manusia sehingga banyak terjadi kasus penularan Covid-19 di lingkungan industri salah satunya karena lingkungan yang kurang mendukung. Kondisi psikologis tersebut disebut dengan Psychological Alienation (keterasingan psikologis) yang dapat menyebabkan masyarakat kurang memiliki rasa empati terhadap lingkungan sekitar sehingga mengurangi kesejahterahan masyarakat. Berikut ini merupakan diagram ke- 
terkaitan antara layout ruangan dengan aktivitas dustri padat karya garmen PT.XYZ. yang dijalankan oleh karyawan di salah satu in-

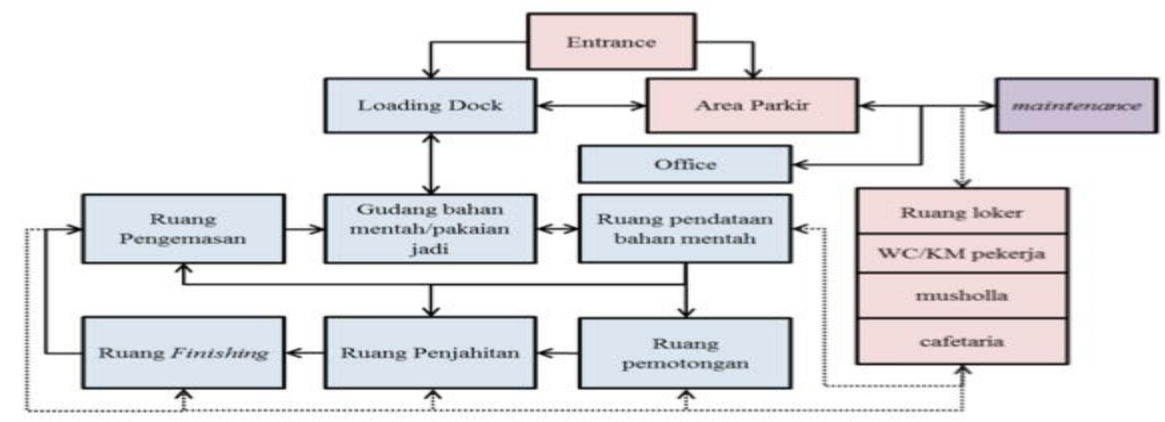

Gambar 1 Contoh Layout Ruangan Pabrik Padat Karya (Garmen) Sumber: Hasil Olahan Penulis, 2021

World Health Organization (WHO) memberikan gambaran umum mengenai moda-moda transmisi SARS-CoV-2. Tujuan dari rencana strategis kesiapan dan penanggulangan Covid-19 adalah untuk mengendalikan Covid -19 dengan menekan transmisi virus dan mencegah penyakit serta kematian terkait. Berikut adalah modamoda transmisi yang memungkinkan penyebaran virus SARS-CoV-2:

1. Transmisi kontak dan droplet

Transmisi droplet saluran napas dapat terjadi ketika seseorang melakukan kontak erat (berada dalam jarak 1 meter) dengan orang terinfeksi yang mengalami gejala-gejala pernapasan (seperti batuk atau bersin) atau yang sedang berbicara atau menyanyi; dalam keadaan-keadaan ini, droplet saluran napas yang mengandung virus dapat mencapai mulut, hidung, mata orang yang rentan dan dapat menimbulkan infeksi. (World Health Organization, 2014)

2. Transmisi melalui udara

Transmisi melalui udara didefinisikan sebagai penyebaran droplet nuclei (aerosol) yang tetap infeksius saat melayang di udara dan bergerak hingga jarak yang jauh. (World Health Organization, 2014)

3. Transmisi fomit

Sekresi saluran pernapasan atau droplet yang dikeluarkan oleh orang yang terinfeksi dapat mengontaminasi permukaan dan benda, sehingga terbentuk fomit (permukaan yang terkontaminasi). Virus dan/atau SARS-CoV-2 yang hidup dan terdeteksi melalui RT-PCR dapat ditemui di permukaan-permukaan tersebut selama berjam-jam hingga berhari-hari, tergantung lingkungan sekitarnya (termasuk suhu dan kelembapan) dan jenis permukaan. (Neeltje van Doremalen et al., 2020; Wang et al., 2020; Yang \& Hung, 2007)

4. Moda-moda tranmisi lain

SARS-CoV-2 juga telah dideteksi di sampelsampel biologis, termasuk urine dan feses beberapa pasien. Sebuah penelitian menemukan SARS-CoV-2 hidup di urine seorang pasien. (Sun et al., 2020)

Tujuan keseluruhan rencana strategis kesiapan dan penanggulangan untuk Covid-19 adalah mengendalikan Covid-19 dengan menekan transmisi virus dan mencegah penyakit serta kematian 
terkait. Untuk mencegah transmisi, WHO merekomendasikan serangkaian komprehensif langkah-langkah yang mencakup:

1. Mengidentifikasi kasus suspek sesegera mungkin, melakukan tes, dan mengisolasi semua kasus (orang yang terinfeksi) di fasilitas yang sesuai;

2. Mengidentifikasi dan mengarantina semua orang yang kontak erat dengan orang yang terinfeksi. Lakukan tes terhadap orang-orang yang menunjukkan gejala sehingga dapat diisolasi jika terinfeksi dan membutuhkan perawatan;

3. Menggunakan masker kain dalam situasi-situasi tertentu, misalnya di ruang publik dan langkah-langkah pencegahan lain seperti penjagaan jarak fisik;

4. Menjalankan kewaspadaan kontak dan droplet untuk tenaga kesehatan yang merawat pasien suspek dan terkonfirmasi Covid-19, dan menjalankan kewaspadaan airborne jika prosedur yang menghasilkan aerosol dijalankan;

5. Terus-menerus menggunakan masker bagi tenaga kesehatan dan pengasuh yang bekerja di area klinis, selama semua kegiatan rutin sepanjang giliran kerjanya;

6. Selalu membersihkan tangan dengan sering, menjaga jarak fisik jika memungkinkan, menjalankan etiket batuk juga bersin, menghindari tempat - tempat yang ramai, tempat - tempat kontak erat, tertutup, tempat - tempat dalam ruangan dengan ventilasi yang buruk, mengenakan masker kain saat berada di ruang tertutup yang terlalu padat untuk melindungi orang lain.
Masalah desain tata letak merupakan masalah strategis dan berdampak signifikan terhadap efisiensi sistem manufaktur (Russel and Taylor, 2011). Fasilitas pabrik dibangun mengikuti alur pergerakan material dan manusia untuk mengoptimalkan efisiensi proses. Di masa pandemi dalam manajemen gedung atau bangunan yang digunakan bersama, memilki banyak pertimbangan dan peraturan yang membatasi penghuninya dalam beraktifitas. Orang yang tinggal dan bekerja di gedung jenis ini memiliki tantangan dengan jarak sosial untuk mencegah penyebaran Covid-19. Saat pandemi berlanjut atau kerja jarak jauh menjadi norma, ruang kantor atau aksesnya harus diubah untuk menciptakan jarak yang lebih besar dan lebih sedikit pilihan tempat duduk. Mengenai kebijakan sterilisasi, perusahaan tertentu bahkan dapat menggunakan penyinaran ultraviolet untuk mendisinfeksi fasilitas gedung di malam hari atau di ruang rapat di setiap jeda penggunaan. Hal ini juga sudah menjadi praktik yang semakin umum di rumah sakit untuk memerangi penyebaran infeksi. WHO telah menghimbau dengan tegas untuk setiap individu menjaga jarak antar pribadi sejauh 1,5 hingga 2 meter untuk meminimalkan risiko infeksi. Namun, penelitian yang lebih baru diterbitkan mendukung hipotesis penularan virus dapat terjadi pada jarak penularan lebih dari 2 meter dari orang yang terinfeksi.

1. Pembatasan akses untuk manajemen khalayak umum yang lebih baik.

Dengan membatasi titik akses/titik kerumunan, kita dapat memantau aktifitas interaksi sosial lebih baik, serta memiliki gambaran yang lebih baik tentang sirkulasi pergerakan manu- 
Santoso, S., Putro, S.S., Fatmawati., A.A., Putri., C.G. \& Sa'dillah. (2021). Disain Mitigasi Risiko Penularan Covid-19 ...

sia. Tindakan adaptif ini diterapkan untuk tempat umum di dalam dan di luar ruangan, termasuk tempat berskala lebih besar yang mungkin memerlukan penutupan akses tertentu (seperti titik akses sekunder atau area khusus lainnya). Penting juga untuk menyediakan pintu akses utama yang terlihat dan mudah dikelola.

2. Membangun akses mobilitas satu arah.

Untuk meningkatkan pengelolaan tempat-tempat umum (di dalam dan di luar ruangan), penting untuk menyesuaikan sirkulasi mobilitas satu arah. Artinya hanya ada satu akses masuk dan satu titik keluar sehingga memudahkan untuk menentukan rute satu arah di setiap sisi koridor ruangan. Dengan belajar dari topik determinisme lingkungan yang lebih luas, dimungkinkan untuk menyesuaikan pengaturan baru di lingkungan fisik, yang dapat merangsang perilaku yang berubah di tempat umum. Dengan mobilitas satu arah, akan mengurangi intensitas berpapasannya antar pekerja dan menekan risiko penularan.

3. Menempatkan pos pemeriksaan untuk monitoring dan pendataan.

Diadaptasi dari langkah-langkah pengendalian mobilitas yang efektif, dan dalam kombinasi dengan dua langkah sebelumnya, dimungkinkan juga untuk mengalokasikan pos pemeriksaan untuk monitoring dan mencatat mobilitas masuk dan keluar dari tempat-tempat umum. Pendekatan ini efektif untuk pencegahan dan pemeriksaan keamanan yang mendeteksi dini gejala penyakit tertentu, seperti pemeriksaan suhu, pendataan akses keluarmasuk pekerja dan tamu, catatan penggunaan

tempat khusus, hingga catatan mobilitas. Penempatan pos pemeriksaan layak dimplementasikan apabila telah memiliki prosedur yang jelas yang mengatur mobilitas manusia.

4. Pembatasan penggunaan fasilitas umum di area publik.

Selama masa pandemi, fasilitas bersama dapat memperbesar risiko penularan penyakit masyarakat (Cheshmehzangi, 2020). Khususnya untuk tempat umum dalam ruangan, pembatasan pada fasilitas dan penggunaan bersama sangat disarankan, seperti pengaturan dalam penggunaan elevator/lift, toilet, hingga kantin pabrik. Disarankan juga untuk membatasi penggunaan perangkat bersama, seperti pendingin terpusat dan sistem pemanas, kipas pendingin besar, dll. Dengan menerapkan pembatasan ini di tempat umum, kita dapat meminimalkan potensi penyebaran penyakit melalui fasilitas/unit, layanan, penggunaan, dan perangkat bersama. Di iklim yang lebih hangat seperti Indonesia, tindakan ini bahkan lebih sulit untuk diterapkan dalam praktiknya. Karenanya, disarankan untuk meminimalkan penggunaan tempat-tempat seperti itu semaksimal mungkin. Selain itu juga sebaiknya agar melakukan sosialisasi mengenai virus Covid19 secara berkala terhadap karyawan. Karena dengan manajemen pengetahuan terhadap virus ini dapat berpengaruh positif dan dapat meningkatkan kesadaran karyawan pentingnya melakukan protokol kesehatan pada saat bekerja. (Harmen, 2018)

\section{METODE PENELITIAN}


Penelitian ini dikembangkan melalui metode kuantitatif - deskriptif, di mana metode FMEA mewakili metode kuantitatif dalam proses simulasi asesmen risiko penularan Covid-19 pada area fasilitas pabrik industri padat karya. Dari hasil simulasi tersebut, dilakukan pengelompokkan setiap ruangan menjadi tiga kategori yaitu ruangan dengan risiko tinggi, medium dan rendah. Metode deskriptif digunakan dalam mendesain mitigasi dari tiap-tiap kategori risiko tinggi dan medium.

Kualitas dari sebuah proses yang dijalankan oleh sebuah perusahaan dapat diukur dengan serangkaian alat pengendali mutu, termasuk di antaranya proses pencegahan penularan Covid19. Salah satu alat yang dapat mengukur risiko dari sebuah proses adalah Failure Modes and Effects Analysis (FMEA). FMEA adalah salah satu metodologi yang digunakan untuk mengidentifikasi, meramalkan dan mengevaluasi sebuah proses, sistem atau desain dengan cara pemberian skor atau nilai yang menggambarkan potensi kegagalan berdasarkan tingkat kejadian (occurrence), seberapa parah efek dari kegagalan tersebut (severity), dan seberapa mudah kegagalan tersebut dapat dideteksi dan diperkirakan (detection) (Stamatis, 2003).

Pada konteks risiko mitigasi pencegahan penularan Covid-19, artikel ini akan berfokus pada layout pabrik, desain akses pergerakan manusia dan pelaksanaan protokol yang disarankan pemerintah dengan menerapkan FMEA di setiap aspek yang memungkinkan menimbulkan potensi penularan. Hasil dari identifikasi melalui FMEA kemudian dijadikan dasar untuk pengem- bangan proposal desain mitigasi pencegahan penularan Covid-19.

Metode FMEA merupakan salah satu metode penilaian risiko proaktif yang paling dikenal dan banyak digunakan di industri (Shebl et al., 2012). Failure Mode adalah kegagalan suatu produk atau proses sesuai dengan fungsinya atau penyebab kegagalan sedangkan Effect Analysis adalah menganalisis akibat yang mungkin terjadi dari setiap kegagalan. Oleh karena itu, FMEA merupakan metode yang dapat digunakan untuk mengidentifikasi semua potensi kegagalan yang mungkin terjadi dalam rancangan dan/atau proses hingga penanganan kasus Covid-19 dapat optimal, serta menganalisis akibat dari setiap kegagalan yang mungkin terjadi dalam mitigasi risiko (Dai, 2011). Secara umum terdapat dua tipe FMEA yaitu FMEA desain dan FMEA proses. FMEA desain, observasi difokuskan pada rancangan mitigasi risiko sedangkan FMEA proses observasi difokuskan pada aktivitas penanganan kasus Covid-19.

Tujuan penggunaan FMEA adalah menentukan tindakan untuk menghilangkan atau mengurangi risiko bahaya terutama untuk prioritas risiko tertinggi. Prioritas risiko ditentukan dari nilai risiko dalam bentuk Risk Priority Number (RPN) dengan beberapa faktor. Risiko kegagalan dan akibatnya ditentukan oleh tiga faktor (Rana \& Belokar, 2017):

1. Tingkat keparahan dari kegagalan jika terjadi (severity)

2. Frekuensi kegagalan yang terjadi (occurrence)

3. Kemungkinan kegagalan untuk terdeteksi sebelum kejadian (detection) 
Santoso, S., Putro, S.S., Fatmawati., A.A., Putri., C.G. \& Sa'dillah. (2021). Disain Mitigasi Risiko Penularan Covid-19 ...

Manfaat dalam menggunakan metode FMEA di antaranya dapat menentukan prioritas untuk setiap tindakan perbaikan, menyediakan dokumen yang lengkap tentang perubahan proses untuk membantu perkembangan selanjutnya, meningkatkan kualias, keandalan, dan keamanan penanganan Covid-19 dan meminimalkan waktu dan biaya. Metode FMEA memerlukan brainstorming oleh karena itu, perlu dibentuk tim FMEA dengan tujuan untuk memberikan perspektif dan experience yang berbeda dari masingmasing individu (Tsai et al., 2017). FMEA dikerjakan menggunakan FMEA Worksheet dan langkah-langkah dalam mengerjakan proses FMEA sebagai berikut (Simsekler et al., 2018):

1. Melakukan kajian proses atau produk.

Tim mengkaji dari blueprint untuk produk FMEA atau flowchart untuk proses FMEA. Untuk case Covid-19, maka tim harus secara langsung melihat menilai dan menelurusi data Covid-19 untuk mengetahui alur dan proses yang terjadi.

2. Tim FMEA melakukan Brainstorming.

Brainstorming menggunakan pendekatan round-robin yaitu pendekatan yang setiap anggota diharuskan menyampaikan ide. Ide yang diberikan berkaitan dengan penyebab kegagalan dari proses penanggulan Covid-19 yang dibahas. Ide-ide dikategorikan berdasarkan tipe kegagalan atau tingkat keparahan kegagalan. Asesment mitigasi risiko perlu fokus secara berkala pada satu bidang tertentu agar dapat berlangsung optimal. (Santoso, 2019)

3. Menentukan tingkat keparahan (level severity). Tingkat keparahan merupakan perkiraan keparahan akibat jika kegagalan terjadi dalam bentuk skor. Faktor-faktor yang berperan dalam menentukan tingkat keparahan dalam proses kasus Covid-19.

4. Menentukan tingkat kejadian (level occurrence).

Tingkat kejadian merupakan frekuensi kegagalan yang terjadi dalam bentuk skor. Tingkat kejadian ditentukan dengan melihat track record kasus Covid-19 selam periode tertentu, dalam Analisa ini yakni minimal dalam satu semester ke belakang.

5. Menentukan tingkat deteksi (level detection). Tingkat deteksi merupakan seberapa besar kemungkinan dapat mendeteksi kegagalan atau akibat dari kegagalan penanganan atau dampak Pandemi Covid-19 dalam bentuk skor. Kunci utamanya dengan mengidentifikasi kontrol saat ini yang dapat mendeteksi kegagalan atau efek akibat kegagalan.

6. Menentukan RPN.

RPN merupakan hasil perkalian masing-masing skor severity, occurrence dan detection. RPN berfungsi sebagai tolak ukur untuk perbandingan dengan RPN total yang direvisi setelah tindakan yang direkomendasikan dilakukan

7. Menentukan prioritas kegagalan untuk tindakan.

Tindakan berdasarkan tingkat prioritas kegagalan melalui nilai RPN.

8. Melakukan tindakan untuk mengurangi risiko. Tindakan dilakukan berdasarkan rekomendasi tindakan dari tim FMEA.

9. Menghitung kembali nilai RPN setelah tindakan. 
Setelah melakukan tindakan, skor baru untuk level severity, occurrence, dan detection harus ditentukan. Nilai RPN yang baru disebut sebagai Resulting RPN. Tidak ada target RPN untuk metode FMEA. Tim FMEA memutuskan seberapa jauh tim harus melakukan perubahan.

\section{HASIL DAN PEMBAHASAN}

Merujuk pada himbauan Satgas Penanggulangan Covid-19 dan WHO, dibutuhkan regulasi khusus di lingkungan pabrik padat karya yang mengatur penggunaan fasilitas dan kegiatan pencegahan penyebaran Covid-19. Penelitian ini akan menggunakan sebuah layout pabrik yang dikembangkan untuk simulasi dan menjadi mo- del layout pabrik padat karya pada umumnya. Pada layout simulasi ini menggunakan lini pengemasan produk (packaging) memanjang dengan para pekerja berbaris mengikuti alur lini conveyor. Layout yang digunakan dalam simulasi pengembangan desain diilustrasikan pada Gambar 2. Layout pabrik yang digunakan dalam simulai memuat area dan ruangan standar yang terdapat pada pabrik padat karya pada umumnya. Layout dan luas area tiap pabrik padat karya di Indonesia bervariasi dan berbeda-beda, sehingga penerapan simulasi ini perlu disesuaikan kembali berdasarkan kondisi tiap pabrik.

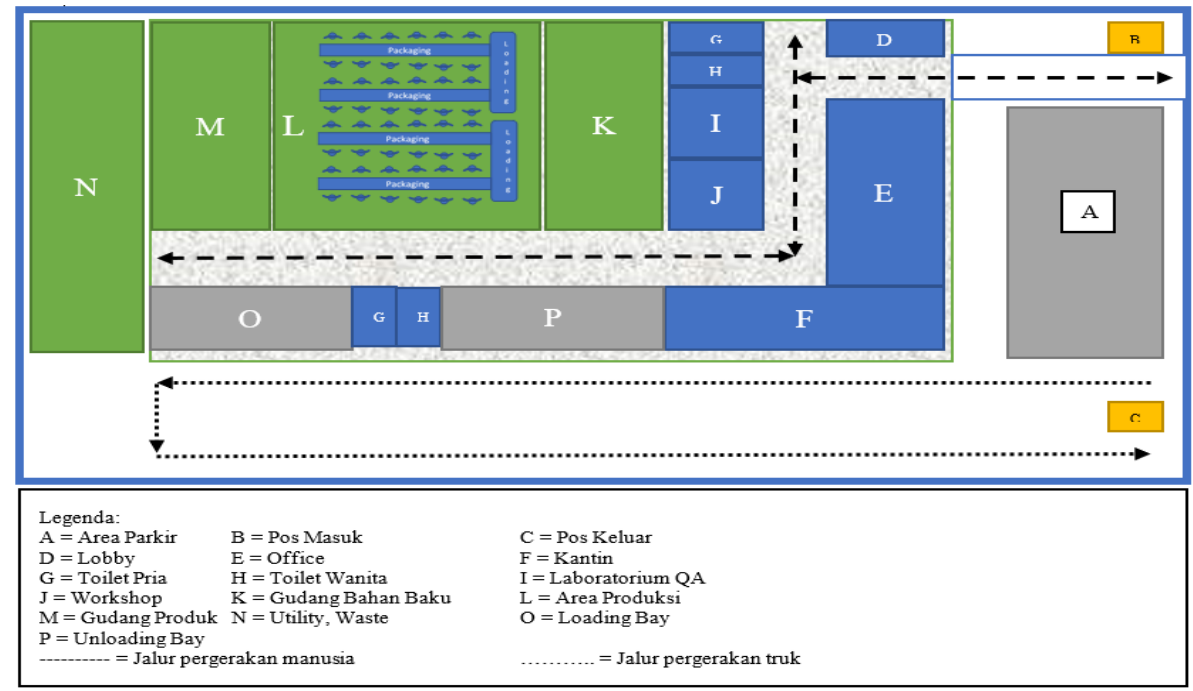

Gambar 2 Simulasi Layout Pabrik Padat Karya Sumber: Hasil Olahan Penulis, 2021

\section{Simulasi Konsentrasi Ruangan}

Di bawah ini merupakan daftar standar besaran ruang yang digunakan dalam pembuatan ruang-ruang dalam bidang arsitektur. Tabel besaran ruang di bawah ini bersifat universal yang dapat diaplikasikan pada semua jenis industri padat karya. Tabel ini menginformasikan standar besaran ruang yang dibutuhkan oleh setiap orang dalam setiap ruang yang dipertimbangkan dengan jenis aktivitas orang di dalam ruang tersebut, misalnya adalah kapasitas orang yang dibutuhkan di area parkir motor dan mobil akan berbeda karena adanya perbedaan aktivitas. Jika parkir motor maka tidak dibutuhkan area yang cukup luas karena tidak membutuhkan manuver 
Santoso, S., Putro, S.S., Fatmawati., A.A., Putri., C.G. \& Sa'dillah. (2021). Disain Mitigasi Risiko Penularan Covid-19 ...

yang luas untuk parkir motor tersebut, lain halnya dengan parkir mobil yang membutuh-kan lahan yang cukup luas karena dibutuhkan $m a-$ nuver yang luas untuk parkir.

Luas kebutuhan total yang ada dalam tabel sifatnya merupakan sebuah asumsi, sehingga kebutuhan luas ini dapat diubah sesuai dengan kebutuhan yang ada pada industri tersebut, namun harus mengikuti standar besaran ruang. Rekomendasi kapasitas jumlah orang dalam keadaan adanya Pandemi Covid-19 dan tidak ada Pandemi Covid-19 adalah berbeda. Hal ini karena adanya ketentuan pemerintah regional mengenai pembatasan jumlah berkala/social distancing, dalam aktivitas perkantoran disebutkan bahwa hanya $50 \%$ karyawan yang dapat beroperasi. Hal inilah yang menjadi dasar dalam merekomendasikan jumlah kapasitas orang di dalam setiap ruang hanya $50 \%$ dari jumlah standar yang berlaku.

Tabel 2 Tabel Standard Besaran Ruang

\begin{tabular}{|c|c|c|c|c|c|c|c|}
\hline No. & Area & $\begin{array}{l}\text { Standard } \\
\text { / orang } \\
\text { (m2) }\end{array}$ & $\begin{array}{c}\text { Asumsi } \\
\text { Jumlah } \\
\text { Karyawan } \\
\text { (orang) }\end{array}$ & $\begin{array}{l}\text { Luas } \\
\text { (m2) }\end{array}$ & $\begin{array}{c}\text { Kebutuhan } \\
\text { Sirkulasi } \\
30 \% \\
(\mathrm{~m} 2) \\
\end{array}$ & $\begin{array}{c}\text { Luas } \\
\text { Kebutuhan } \\
\text { Total } \\
\text { (m2) }\end{array}$ & $\begin{array}{c}\text { Rekomendasi } \\
\text { Kapasitas } \\
\text { saat Covid-19 } \\
\text { (orang) }\end{array}$ \\
\hline 1 & Pintu Pekerja/Tamu & 0,65 & 200 & 130,00 & 39,00 & 169,00 & 100 \\
\hline 2 & Loading-Unloading Dock & 24,00 & 4 & 96,00 & 28,80 & 124,80 & 2 \\
\hline 3 & Parkir Motor 70\% & 2,00 & 476 & 95200 & 285,60 & 1237,60 & 238 \\
\hline 4 & Parkir Mobil 20\% & 10,00 & 20 & 200,00 & 48,00 & 208,00 & 10 \\
\hline \multirow[t]{5}{*}{5} & Office: & & & & & & \\
\hline & - Ruang Direktur & 14,72 & 1 & 14,72 & 4,42 & 19,14 & 1 \\
\hline & - Ruang Manager & 7,92 & 4 & 31,68 & 9,50 & 41,18 & 4 \\
\hline & - Ruang Staff & 6,70 & 50 & 335,00 & 100,50 & 435,50 & 25 \\
\hline & - Meeting Room & 2,00 & 25 & 50,00 & 15,00 & 65,00 & 13 \\
\hline 6 & Lobby & 2,00 & 10 & 20,00 & 6,00 & 26,00 & 5 \\
\hline 7 & $\begin{array}{l}\text { Gudang Bahan Mentah / } \\
\text { Produk \& Utility }\end{array}$ & 20,00 & 10 & 200,00 & 60,00 & 260,00 & 5 \\
\hline 8 & Area Produksi & 3,99 & 30 & 119,70 & 35,91 & 155,61 & 15 \\
\hline 9 & Kamar Mandi & 3,29 & 30 & 98,70 & 29,61 & 128,31 & 15 \\
\hline 10 & Kantin & 1,60 & 300 & 480,00 & 144,00 & 624,00 & 150 \\
\hline \multirow[t]{2}{*}{11} & Ruang Maintenance Lab & 10,00 & 5 & 50,00 & 15,00 & 65,00 & 2 \\
\hline & TOTAL & & & 3942,75 & 1170,82 & 5073,57 & \\
\hline
\end{tabular}

Sumber: Diolah dari Ernst Neufert, 1996 dan Time Server Standards, 1991

\section{Assessment FMEA}

Pendekatan FMEA mengidentifikasi potensi penularan Covid-19 dengan RPN (Risk Priority Number) yang didapat dari hasil perhitungan Severity x Occurance x Detectability (Kristyanto et al., 2013) dan FMEA pada penelitian ini berfokus pada identifikasi jenis area dan bangunan yang berpotensi menjadi tempat penularan Covid-19 melalui analisa kapasitas dan intensitas penggunaannya, dalam kategori berikut:

1. Indikator kategori 1:
Luas bangunan antara $3 \mathrm{~m}$ persegi $-1000 \mathrm{~m}$ persegi. Lalin orang tinggi dalam satu waktu atau kontinu, social distancing kurang dari $1 \mathrm{~m}$.

2. Indikator kategori 2 :

Luas bangunan antara $3 \mathrm{~m}$ persegi $-1000 \mathrm{~m}$ persegi. Lalin orang sedang dalam satu waktu atau tidak kontinu social distancing lebih dari $1 \mathrm{~m}<2$ $\mathrm{m}$.

3. Indikator kategori 3 :

Luas bangunan antara $3 \mathrm{~m}$ persegi $-1000 \mathrm{~m}$ persegi. Lalin orang rendah dalam satu waktu 
atau tidak kontinu, social distancing mudah diterapkan. Area lalin barang atau armada.

Tabel 3 Simulasi Analisa FMEA Fasilitas Pabrik pada Risiko Penularan Covid-19

\begin{tabular}{|c|c|c|c|c|c|c|c|c|c|c|}
\hline \multirow[b]{2}{*}{ No } & \multirow{2}{*}{\begin{tabular}{|c|c|}
$\begin{array}{c}\text { Process } \\
\text { Step/Input }\end{array}$ & \\
& \\
& \\
Apa yang & $\mathrm{k}$ \\
sedang \\
diselidiki?
\end{tabular}} & \multirow{2}{*}{\begin{tabular}{c|}
$\begin{array}{c}\text { Potential Failure } \\
\text { Mode }\end{array}$ \\
\\
Dalam hal apa \\
kondisi atau aktifitas \\
tersebut bisa \\
dikatakan \\
salah/gagal? \\
\end{tabular}} & \multirow{2}{*}{\begin{tabular}{|c|}
$\begin{array}{c}\text { Potential Failure } \\
\text { Effects }\end{array}$ \\
\\
Apa dampaknya \\
jika kegagalan atau \\
kesalahan tersebut \\
tidak dicegah atau \\
diperbaiki?
\end{tabular}} & \multirow[b]{2}{*}{ 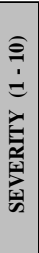 } & \multirow{2}{*}{\begin{tabular}{|c|} 
Potential Causes \\
\\
Apa yang menyebabkan \\
kondisi atau aktifitas tersebut \\
dikatakan salah? (bagaimana \\
hal itu bisa terjadi?)
\end{tabular}} & \multirow[b]{2}{*}{ 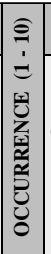 } & \multirow[b]{2}{*}{ 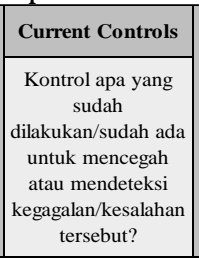 } & \multirow[b]{2}{*}{ 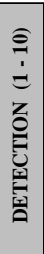 } & \multirow[b]{2}{*}{$\underset{\beth}{\simeq}$} & \multirow[t]{2}{*}{ Action Recommended } \\
\hline & & & & & & & & & & \\
\hline \multirow[t]{2}{*}{1} & \multirow[t]{2}{*}{\begin{tabular}{|l|}
$\begin{array}{l}\text { Pos keluar- } \\
\text { masuk orang }\end{array}$ \\
\end{tabular}} & \begin{tabular}{|l|} 
Penumpukan orang \\
baik \\
karyawan/tamu \\
\end{tabular} & \begin{tabular}{|l|} 
Potensi \\
penularan Covid- \\
19 tinggi
\end{tabular} & 8 & $\begin{array}{l}\text { Tidak ada antrian atau } \\
\text { pembatas jarak }\end{array}$ & 7 & Sistem satu pintu & 6 & 336 & $\begin{array}{l}\text { Buat antrian menggunakan garis } \\
\text { pembatas }\end{array}$ \\
\hline & & $\begin{array}{l}\text { Tamu/karyawan } \\
\text { yang masuk tidak } \\
\text { terdeteksi }\end{array}$ & \begin{tabular}{|l|} 
Tidak \\
terassesment \\
orang yang \\
memiliki gejala \\
Covid-19 \\
\end{tabular} & 8 & $\begin{array}{l}\text { Tidak ada protokol untuk } \\
\text { melakukan assesment }\end{array}$ & 7 & Personal security & 5 & 280 & \begin{tabular}{|l|} 
Buat protokol early assesment sesuai \\
regulasi dan training terhadap security. \\
Pastikan yang memiliki gejala tidak \\
mendapatkan akses masuk
\end{tabular} \\
\hline \multirow[t]{2}{*}{2} & \multirow[t]{2}{*}{$\begin{array}{l}\text { Parkir } \\
\text { Motor }\end{array}$} & $\begin{array}{l}\text { Parkir terlalu } \\
\text { berdempetan }\end{array}$ & \begin{tabular}{|l|} 
Potensi \\
penularan Covid- \\
19 tinggi
\end{tabular} & 7 & \begin{tabular}{|l|} 
Tidak ada pengaturan \\
jarak parkir dan jalur satu \\
arah
\end{tabular} & 7 & $\begin{array}{l}\text { Cat pembatas } \\
\text { parkir motor }\end{array}$ & 7 & 343 & $\begin{array}{l}\text { Pasang label pembatas parkir atau } \\
\text { lakukan blokade pada parkir }\end{array}$ \\
\hline & & $\begin{array}{l}\text { Orang berkumpul } \\
\text { di area parkir }\end{array}$ & \begin{tabular}{|l|}
$\begin{array}{l}\text { Potensi } \\
\text { penularan Covid- } \\
19 \text { tinggi }\end{array}$ \\
\end{tabular} & 8 & $\begin{array}{l}\text { Tidak ada regulasi dan } \\
\text { pengawasan }\end{array}$ & 6 & CCTV & 6 & 288 & $\begin{array}{l}\begin{array}{l}\text { Pasang peringatan dan protokol di area } \\
\text { parkir }\end{array} \\
\end{array}$ \\
\hline \multirow[t]{2}{*}{3} & \multirow[t]{2}{*}{$\begin{array}{l}\text { Meeting } \\
\text { room }\end{array}$} & $\begin{array}{l}\text { Meeting dilakukan } \\
\text { full seat }\end{array}$ & \begin{tabular}{|l|} 
Penularan Covid- \\
19 melalui \\
surface area
\end{tabular} & 8 & $\begin{array}{l}\text { Tidak ada pengaturan } \\
\text { jumlah kursi selama } \\
\text { pandemik }\end{array}$ & 7 & $\begin{array}{l}\text { Jadwal cleaning } \\
\text { reguler }\end{array}$ & 5 & 280 & $\begin{array}{l}\text { Lakukan pembatasan jumlah kursi } \\
\text { dengan untuk membatasi jumlah } \\
\text { peserta }\end{array}$ \\
\hline & & \begin{tabular}{|l|} 
Jadwal meeting \\
padat
\end{tabular} & \begin{tabular}{|l|} 
Penularan covid- \\
19 melalui \\
droplet dan \\
surface area
\end{tabular} & 8 & $\begin{array}{l}\text { Tidak ada pembatasan } \\
\text { meeting offline }\end{array}$ & 7 & \begin{tabular}{|l|} 
Dokumentasi \\
jadwal meeting
\end{tabular} & 4 & 224 & $\begin{array}{l}\text { Lakukan meeting secara virtual atau } \\
\text { kategorisasi meeting berdasarkan } \\
\text { urgensinya }\end{array}$ \\
\hline \multirow[t]{2}{*}{4} & \multirow[t]{2}{*}{ Lobby } & $\begin{array}{l}\text { Jumlah kursi yang } \\
\text { tersedia }\end{array}$ & $\begin{array}{l}\text { Orang dapat } \\
\text { duduk di kursi } \\
\text { yang tersedia } \\
\end{array}$ & 8 & $\begin{array}{l}\text { Dapat menjadi area yang } \\
\text { terkontaminasi droplet }\end{array}$ & 7 & Cleaning reguler & 5 & 280 & $\begin{array}{l}\text { Batasi jumlah kursi yang dapat } \\
\text { diduduki }\end{array}$ \\
\hline & & $\begin{array}{l}\text { Kemudahan akses } \\
\text { ke lobby }\end{array}$ & $\begin{array}{l}\text { Social distancing } \\
\text { tidak dapat } \\
\text { dilaksanakan }\end{array}$ & 8 & \begin{tabular}{|l|} 
Tidak ada pembatasan \\
masuk untuk orang ataupun \\
lobby regulation
\end{tabular} & 8 & Security personal & 5 & 320 & $\begin{array}{l}\text { Lakukan administrasi kontrol akses ke } \\
\text { lobby berdasarkan urgensinya }\end{array}$ \\
\hline 5 & \begin{tabular}{|l} 
Area \\
Produksi
\end{tabular} & \begin{tabular}{|l|} 
Penumpukan para \\
pekerja di satu titik
\end{tabular} & \begin{tabular}{|l|} 
Social distancing \\
tidak dapat \\
dilaksanakan
\end{tabular} & 8 & $\begin{array}{l}\text { Tidak ada jarak atau space } \\
\text { untuk bekerja antara } \\
\text { pekerja }\end{array}$ & 8 & APD & 5 & 320 & $\begin{array}{l}\text { Atur jumlah pekerja dan jenis } \\
\text { pekerjaan serta batasan area kerja }\end{array}$ \\
\hline 6 & $\begin{array}{l}\text { K. mandi } \\
\text { dan toilet }\end{array}$ & \begin{tabular}{|l|} 
Orang keluar \\
masuk toilet secara \\
bergantian
\end{tabular} & $\begin{array}{l}\text { Penularan tinggi } \\
\text { covid-19 pada } \\
\text { bidang surface }\end{array}$ & 8 & $\begin{array}{l}\text { Masuk toilet secara } \\
\text { bersamaan dan sanitasi } \\
\text { area }\end{array}$ & 8 & Cleaning reguler & 5 & 320 & $\begin{array}{l}\text { Batasi jumlah orang yang masuk dan } \\
\text { lakukan sanitasi lebih sering }\end{array}$ \\
\hline 7 & Kantin & $\begin{array}{l}\text { Jadwal makan } \\
\text { siang }\end{array}$ & $\begin{array}{l}\text { Penularan tinggi } \\
\text { covid-19 antar } \\
\text { pekerja }\end{array}$ & 9 & \begin{tabular}{|l|} 
Tidak ada regulasi \\
penggunaan kantin dan \\
batas pemanfaatan ruangan
\end{tabular} & 8 & $\begin{array}{l}\text { Makan dengan nasi } \\
\text { box }\end{array}$ & 7 & 504 & $\begin{array}{l}\text { Lakukan pembatasan jumlah orang dan } \\
\text { surface area }\end{array}$ \\
\hline 9 & $\begin{array}{l}\text { Office Staff } \\
\text { room }\end{array}$ & $\begin{array}{l}\text { Aktifitas kerja } \\
\text { rutin }\end{array}$ & $\begin{array}{l}\text { Penularan tinggi } \\
\text { covid-19 antar } \\
\text { staff }\end{array}$ & 5 & $\begin{array}{l}\text { Jumlah staff dan aktifitas } \\
\text { mobile yang tinggi dalam } \\
\text { ruangan }\end{array}$ & 4 & APD & 5 & 100 & \begin{tabular}{|l|} 
Lakukan pembatasan jumlah orang \\
dalam satu ruangan dengan opsi WFH
\end{tabular} \\
\hline \multirow[t]{2}{*}{10} & \multirow[t]{2}{*}{\begin{tabular}{|l|} 
Laboratoriu \\
m QA dan \\
Workshop
\end{tabular}} & $\begin{array}{l}\text { Mobilisasi petugas } \\
\text { Lab tinggi di } \\
\text { dalam ruangan }\end{array}$ & $\begin{array}{l}\text { Tertular gejala } \\
\text { melalui surface } \\
\text { area atau rekan } \\
\text { kerja }\end{array}$ & 6 & $\begin{array}{l}\text { Gejala sakit pada petugas } \\
\text { tidak teridentifikasi dan } \\
\text { tidak ada prosedur } \\
\text { dekontaminasi personal } \\
\text { sebelum memasuki Lab }\end{array}$ & 5 & $\begin{array}{l}\text { APD dan baju } \\
\text { pelindung }\end{array}$ & 5 & 150 & $\begin{array}{l}\text { Sosialisasikan kebijakan kriteria } \\
\text { sickness leave dan sediakan ruang } \\
\text { dekontaminasi }\end{array}$ \\
\hline & & Mobilisasi orang & $\begin{array}{l}\text { Penularan } \\
\text { droplet melalui } \\
\text { orang }\end{array}$ & 8 & $\begin{array}{l}\text { Saat ada pekerjaan } \\
\text { mendadak dan skalanya } \\
\text { besar }\end{array}$ & 6 & $\begin{array}{l}\text { Worksop sudah } \\
\text { memiliki batasan } \\
\text { area yang jelas } \\
\text { antara mekanik } \\
\text { dengan elektrik } \\
\end{array}$ & 3 & 144 & $\begin{array}{l}\text { Batasi jumlah pekerjaan di workshop } \\
\text { dan jumlah pekerja yang terlibat. Serta } \\
\text { pertimbangkan opsi untuk vendor-kan }\end{array}$ \\
\hline \begin{tabular}{|l|}
12 \\
\end{tabular} & $\begin{array}{l}\text { Loading- } \\
\text { unloading } \\
\text { Bay }\end{array}$ & $\begin{array}{l}\text { Para sopir } \\
\text { berkumpul di } \\
\text { waiting station }\end{array}$ & \begin{tabular}{|l|} 
Penularan covid- \\
19 melalui orang
\end{tabular} & 6 & $\begin{array}{l}\text { Sopir jenuh di dalam } \\
\text { kabin }\end{array}$ & 4 & \begin{tabular}{|l|} 
Driver wajib \\
menggunakan \\
masker dan berada \\
di kabin truck \\
selama muatan \\
berlangsung
\end{tabular} & 5 & 120 & $\begin{array}{l}\text { Blok akses ke area ruang tunggu } \\
\text { station dan batasi jumlah truck sesuai } \\
\text { kebutuhan }\end{array}$ \\
\hline \begin{tabular}{|l|l|}
13 \\
\end{tabular} & $\begin{array}{l}\text { Pos keluar- } \\
\text { masuk } \\
\text { armada } \\
\text { truck }\end{array}$ & $\begin{array}{l}\text { Tamu atau } \\
\text { karyawan } \\
\text { berkunjung }\end{array}$ & $\begin{array}{l}\text { Penularan } \\
\text { melalui surface } \\
\text { area }\end{array}$ & 9 & $\begin{array}{l}\text { Bertamu tanpa mengikuti } \\
\text { protokol kesehatan }\end{array}$ & 4 & $\begin{array}{l}\text { APD, sanitize dan } \\
\text { pembatasan tamu }\end{array}$ & 3 & 108 & $\begin{array}{l}\text { Tidak ada kunjungan selama pandemik } \\
\text { Covid-19. Kunjungan lakukan secara } \\
\text { virtual }\end{array}$ \\
\hline \begin{tabular}{|l|}
14 \\
\end{tabular} & $\begin{array}{l}\text { Gudang \& } \\
\text { Utility }\end{array}$ & \begin{tabular}{|l|} 
Penumpukan \\
pekerja dalam satu \\
waktu
\end{tabular} & $\begin{array}{l}\text { Penularan } \\
\text { droplet melalui } \\
\text { orang }\end{array}$ & 7 & $\begin{array}{l}\text { Bila ada satu pekerja rutin } \\
\text { memiliki gejala Covid-19 }\end{array}$ & 5 & $\begin{array}{l}\text { Utility hanya } \\
\text { dimasuki orang } \\
\text { tertentu }\end{array}$ & 2 & 70 & $\begin{array}{l}\text { Lakukan pekerjaan maintenance } \\
\text { berkala dan setiap tim menggunakan } \\
\text { protokol kesehatan secara maksimal }\end{array}$ \\
\hline
\end{tabular}

Sumber : Hasil Olahan Penulis, 2021. 
Selanjutnya langkah yang dilakukan yakni melakukan evaluasi terhadap nilai RPN yang muncul dari perkalian antara (S), (O), dan (D). Tahap evaluasi ini yakni berupa mitigasi kriteria penerimaan risiko atau yang disebut sebagai risk acceptability criteria. Dalam penelitian ini penulis mengadopsi metode dari standar ISO 14971 yang disederhanakan menjadi dua kategori mitigasi risiko berdasarkan derajat toleransi untuk setiap mode kegagalan (failure). Adapun kategori tersebut yakni:

1. Tolerable risk yang didefinisikan sebagai risiko rendah dimana risiko/bahaya penularan Covid 19 saat design tidak direalisasikan maka risiko dapat diterima atau acceptable.

2. Intolerable risk yang didefinisikan sebagai risiko tinggi dimana risiko/bahaya dari penularan Covid-19 saat design tidak direalisasikan maka risiko tidak dapat diterima atau not acceptable.

Model derajat toleransi yang digunakan dalam penelitian ini berdasarkan batas nilai dari hasil perkalian ketiga mode yakni 1000, karena nilai tertinggi dari setiap rangking pada mode yakni 10, maka rentang nilainya antara 100-1000 yang dibagi ke dalam 10 kategori. Adapun penerapannya yakni sebagai berikut:
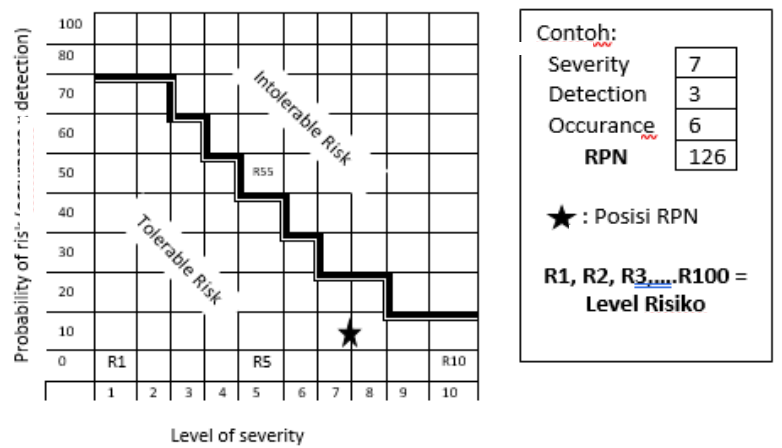

Gambar 3 Kriteria Penerimaan Risiko Sumber : Unit Engineering PT MAK, 2008
Jika dari hasil evaluasi berdasarkan derajat kriteria risiko di atas dan didapatkan bahwa design yang ada dinyatakan tolerance dan tidak menyebabkan penularan Covid-19 maka design mitigasi dapat diterima atau diterapkan. Namun jika design memenuhi kriteria intolerance, maka perlu dilakukan tindakan pengendalian untuk mengurangi nilai RPN atau nilai risiko yang ada agar dapat diterima atau diterapkan. Maka berdasarkan kriteria di atas maka dapat dilakukan mitigasi lanjutan bagi nilai RPN yang not acceptable (risiko tinggi).

\section{Mitigasi Risiko Tinggi}

Area produksi merupakan area di mana setiap pekerja akan berada dalam satu ruangan secara terus-menerus dalam satu waktu shift kerja, dapat berlangsung mulai dari 6 hingga 12 jam bergantung pada kebijakan tiap perusahaan. Termasuk area-area lain dengan luas terbatas dan hanya dapat memuat orang dalam jumlah yang kecil seperti toilet, meeting room dan kantin. Pada perusahaan padat karya, jarak area kerja antara satu pekerja dengan pekerja lainnya tidak memberikan area aman yang cukup untuk mengurangi risiko terjadinya penularan, dalam hal ini sesuai rekomendasi WHO adalah 1,5 - 2 meter. Mitigasi risiko pada area ini didesign melalui langkah-langkah berikut:

1. Perubahan design layout produksi.

Bila area produksi memungkinkan, organisasi padat karya dapat melakukan perubahan layout produksi untuk meminimalisir risiko dan melindungi pekerja produksinya. Hal ini dapat dilakukan melalui perpanjangan jalur conveyor untuk menciptakan jarak aman antara satu pekerja dengan pekerja lainnya. 
Perpanjangan jalur conveyor produksi dapat dilakukan secara lurus linear (opsi 1), maupun dibuat mengikuti pola zig-zag untuk mengako- modasi area yang terbatas (Opsi 2), seperti diilustrasikan pada Gambar 4.

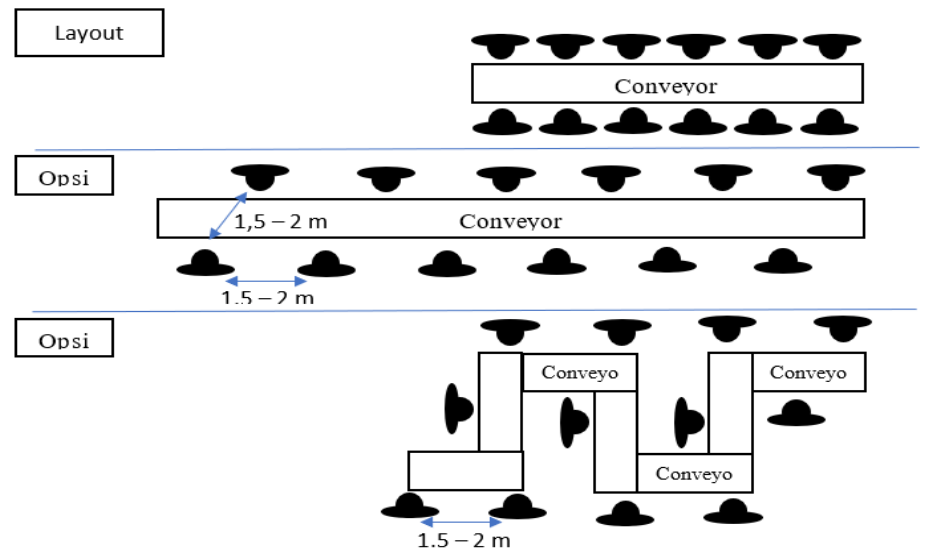

Gambar 4 Mitigasi Risiko dengan Desain Opsional Layout Area Produksi Sumber: Hasil Olahan Penulis, 2021

2. Instalasi partisi antar pekerja.

Selain pembatasan jarak antar pekerja melalui perubahan layout produksi, organisasi padat karya juga dapat membatasi bauran droplet antar pekerja dengan melakukan instalasi partisi di antara para pekerja. Partisi ini diharapkan meminimalisir perbauran droplet dan penyebaran virus melalui udara. Instalasi partisi ini diilustrasikan pada Gambar 5 di bawah. Partisi yang diinstalasikan dibuat dengan bahan material yang transparan berupa kaca, mika atau lembaran PVC plastik fleksible tanpa rongga. Bahan yang transparan memungkinkan pekerja untuk tetap memiliki keleluasaan visual dalam bekerja dan berkomunikasi dengan pekerja lainnya.
3. Membatasi kapasitas karyawan dalam menggunakan fasilitas kantor.

Mitigasi risiko tinggi selanjutnya yang dapat dilakukan adalah dengan membatasi jumlah fasilitas yang ada, sebagai contoh adalah ilustrasi di bawah ini. Pembatasan jumlah kursi di Ruang Rapat menjadi salah satu cara mitigasi risiko penyebaran Covid-19. Jika dalam keadaan normal, dalam sebuah ruangan rapat berukuran 60-80 m2 dapat menampung 24 orang, maka kita melakukan pembatasan jumlah kursi hanya sebanyak 12 orang (50\% dari jumlah kapasitas yang disarankan menurut Pergub Jakarta Nomor 51 Tahun 2020).

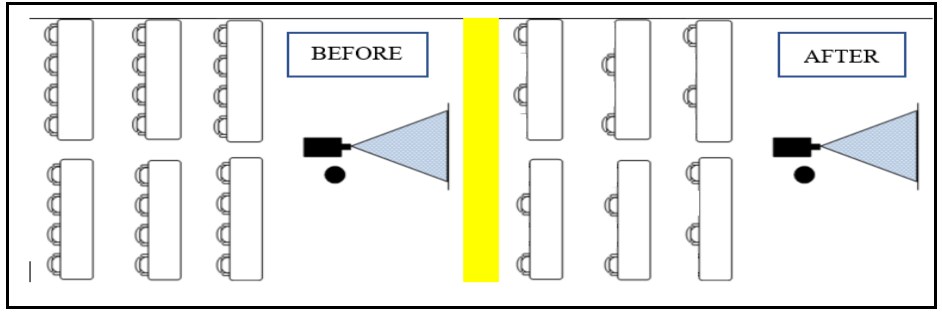

Gambar 5 Instalasi Ruang Rapat Sumber: Data Olahan Penulis, 2021 
Santoso, S., Putro, S.S., Fatmawati., A.A., Putri., C.G. \& Sa'dillah. (2021). Disain Mitigasi Risiko Penularan Covid-19 ...

Hal ini juga dapat diterapkan di area lobby utama mengingat di lobby merupakan banyak terjadi keluar masuk orang sehingga sangat rentan terjadi penularan Covid-19.

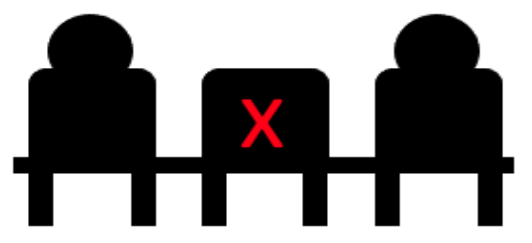

Gambar 6 Instalasi Ruang Tunggu Lobby Sumber: Hasil Olahan Penulis, 2021

4. Melakukan pembatasan jumlah karyawan yang keluar masuk dalam suatu ruangan.

Hal ini dilakukan agar dapat melakukan pendeteksian pada jumlah orang yang sedang berada di dalam ruangan, agar tidak terjadi over capacity di dalam ruangan tersebut, sehingga pihak management kantor dapat melakukan regulasi untuk melarang orang untuk masuk ke dalam ruangan jika sudah melebihi kapasitas. Salah satu ruangan cukup tinggi risikonya adalah di toilet. Pembatasan yang dilakukan adalah dengan membuat regulasi bahwa karyawan harus mengganti sepatu mereka dengan sandal yang telah disiapkan di depan toilet. Sandal yang ada di depan toilet dibatasi jumlahnya dan disesuaikan dengan jumlah toilet yang ada, sehingga orang yang masuk dalam toilet dapat dibatasi dan disesuaikan dengan kapasitasnya.

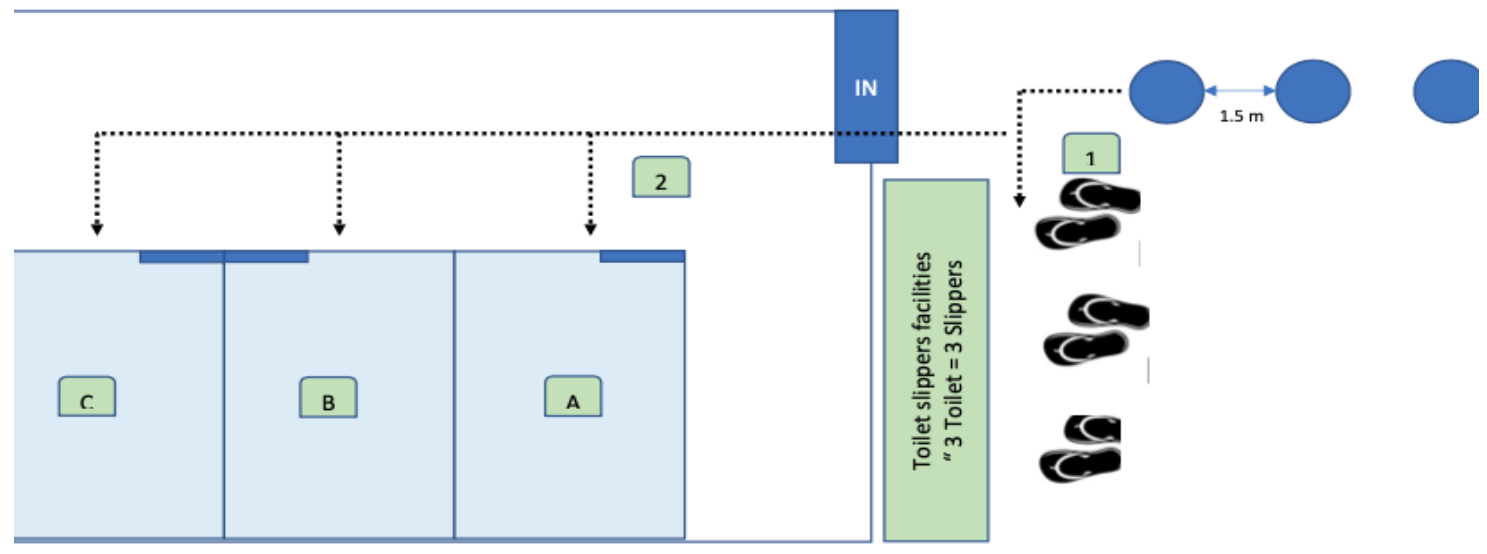

Gambar 7 Ilustrasi Pembatasan di Toilet Sumber : Hasil Olahan Penulis, 2021

5. Pembatasan Pintu Pos Keluar Masuk

Mitigasi yang dilakukan di area pintu keluar masuk area pabrik yang memiliki resiko yang cukup tinggi. Mitigasi ini akan memeriksa kondisi fisik dari pekerja dan tamu yang akan masuk ke areal pabrik, sehingga dapat menghindari masuknya pekerja atau tamu yang kondisi kesehatannya tidak baik atau memilki gejala tertular Covid-19. Pada area pintu masuk terdapat beberapa mitigasi yang akan dilakukan, mulai dari arah kedatangan hingga tamu/karyawan terse- but keluar dari kantor. Berikut ini merupakan ilustrasi yang menggambarkan mitigasi yang akan dilakukan di pintu keluar masuk. Terdapat emergency acces di ujung ruangan sebagai tempat mengisolasi bagi pengunjung/karyawan terdeteksi memiliki gejala Covid-19. Proses isolasi bersifat sementara sebagai sarana untuk menunggu tindakan selanjutnya dari tenaga kesehatan atau Satgas Covid-19 yang akan datang setelah menerima informasi dari petugas jaga pos. 


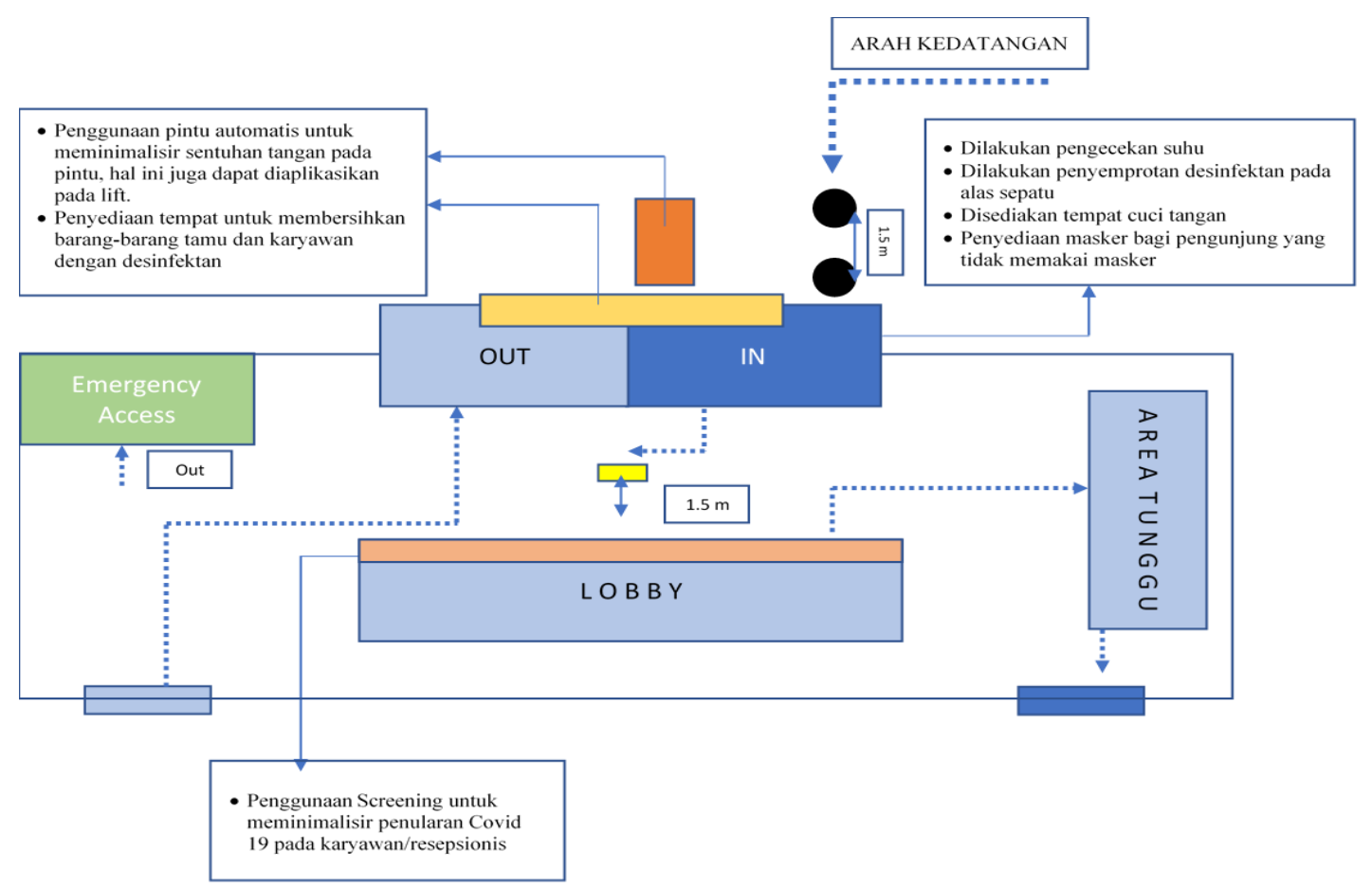

Gambar 8 Ilustrasi Pembatasan di Pintu Keluar Masuk Sumber : Hasil Olahan Penulis, 2021

6. Desain layout parkir sepeda motor.

Areal parkir sepeda motor termasuk area dengan risiko tinggi penularan Covid-19. Jarak antar motor dan ketibaan premotor yang bersamaan dalam rentang waktu yang dekat menyebabkan risiko yang tinggi. Perubahan layout penempatan kendaraan sepeda motor perlu dilakukan untuk menciptakan jarak aman antar pemotor saat proses parkir kendaraan dilakukan. Gambar 10 menunjukkan desain layout untuk mengakomodasi kebutuhan tersebut.

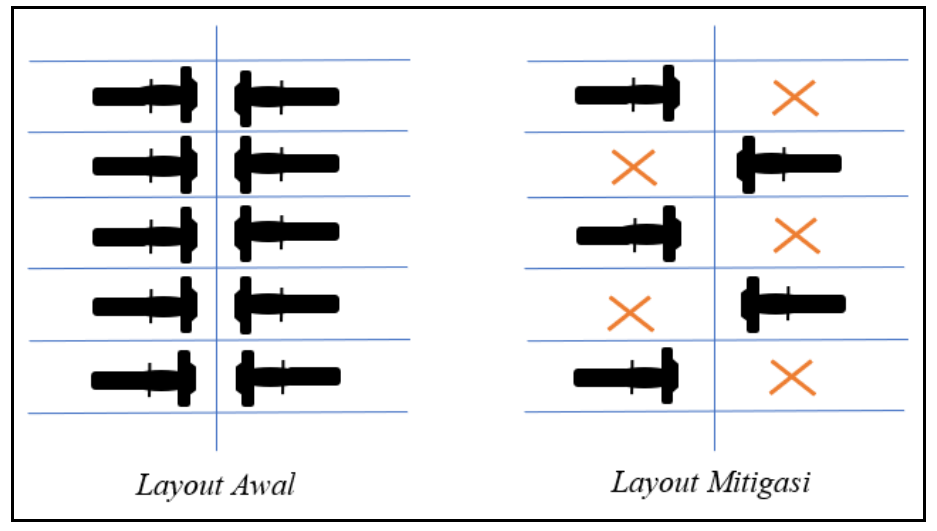

Gambar 9 Ilustrasi Perubahan Layout Parkir Sepeda Motor Sumber: Hasil Olahan Penulis, 2021

7. Pembatasan jumlah penggguna kantin.

Pembatasan yang dilakukan di area kantin hampir sama dengan yang dilakukan pada area ruang rapat dan lobby, yaitu dengan mengurangi jum- lah kapasitas yang ada di dalam kantin. Sirkulasi udara menjadi hal yang sangat penting untuk diterapkan di area kantin sehingga pemilihan lokasi kantin harus dipertimbangkan untuk men- 
dapatkan sirkulasi udara yang bersih. Selain itu, penerapan social distancing pada area kantin juga memberikan dampak kepada jumlah pengunjung, sehingga perlu ada penerapan shift pada karyawan terutama untuk jam istirahat, agar dapat mengurangi penyebaran Covid-19 di area kantin.

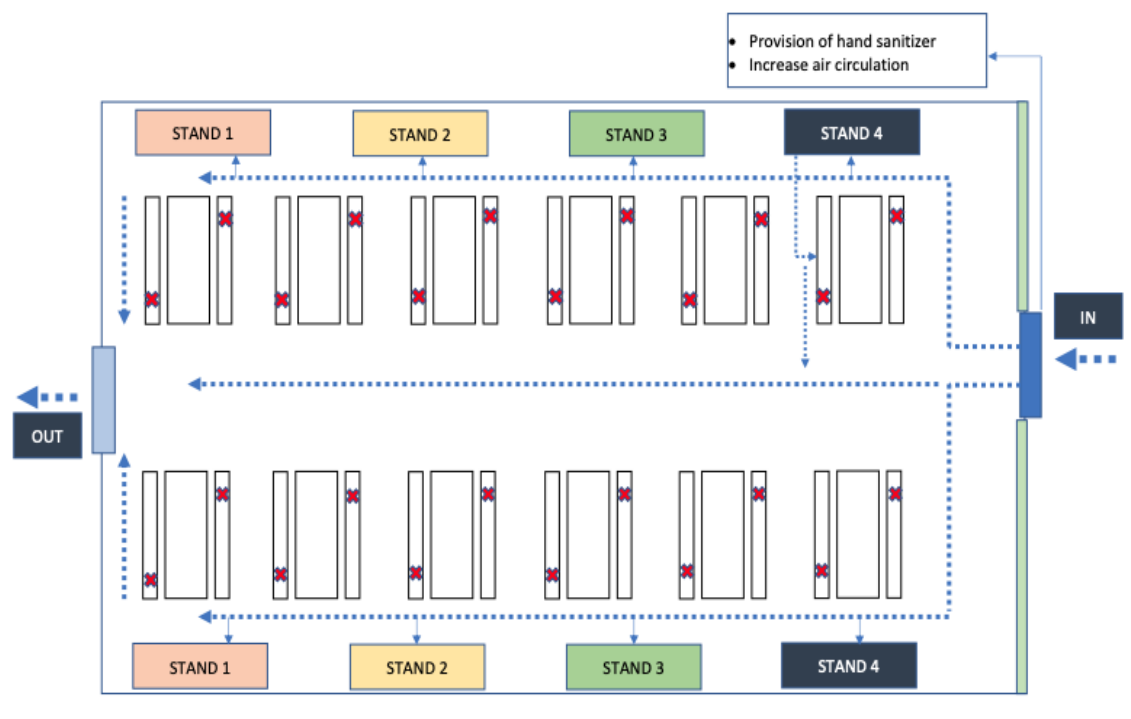

Gambar 10 Ilustrasi Pembatasan di Kantin Sumber : Hasil Olahan Penulis, 2021

\section{Mitigasi Risiko Medium dan Rendah - Pengaturan Mobilitas Satu Arah}

Untuk area kerja dengan hasil asesmen beresiko rendah dari FMEA di atas, khususnya area koridor dan jalan manusia, dengan tujuan mengurangi interaksi manusia di dalam pabrik, diperlukan adanya pengaturan jalur pergerakan manusia dalam berpindah dari satu posisi ke posisi lainnya. Pengaturan jalur tersebut dapat berupa pemisahan arah pergerakan manusia agar tidak bercampur dalam satu lajur. Untuk pabrik dengan area koridor panjang dan memiliki jalur keluar dan masuk yang berbeda akan mudah mendesain agar koridor dan jalan manusia dibuat satu arah saja. Namun untuk pabrik dengan koridor dan jalur manusia yang terbatas, dapat memasang pagar pembatas atau marka pembatas dan petunjuk arah yang membatasi jalan dan koridor menjadi 2 bagian dan 2 arah mobilitas, seperti ilustrasi pada Gambar 11.

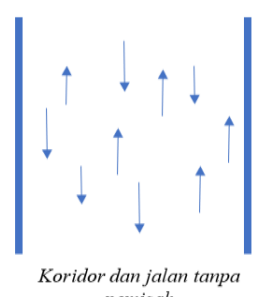

pemisah

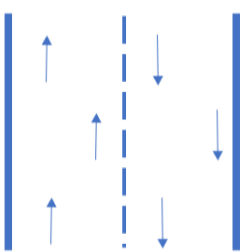

Koridor dan jalan dengan pagar atau marka pemisa
Gambar 11 Perbandingan Mobilitas Koridor atau Jalan Dengan dan Tanpa Pemisah Sumber : Hasil Olahan Penulis, 2021

Pemisahan koridor dan jalan menjadi 2 bagian bertujuan mengurangi risiko penularan Covid19 antar grup shift kerja. Pemisahan jalur diharapkan mampu menciptakan jarak antara grup shift kerja satu dengan shift selanjutnya. Sehingga apabila terjadi penyebaran virus Covid-19 pada satu grup shift kerja, risiko penularan pada grup shift kerja lainnya dapat ditekan, dan sebuah grup shift kerja dapat melakukan isolasi mandiri, sementara grup shift kerja lainnya dapat tetap beraktivitas di area pabrik sesuai kebutuhan bisnis. Dalam penga- 
turan mobilitas manusia di area pabrik ini, meruseperti yang diilustrasikan.

bah arah mobilitas dalam layout pabrik menjadi

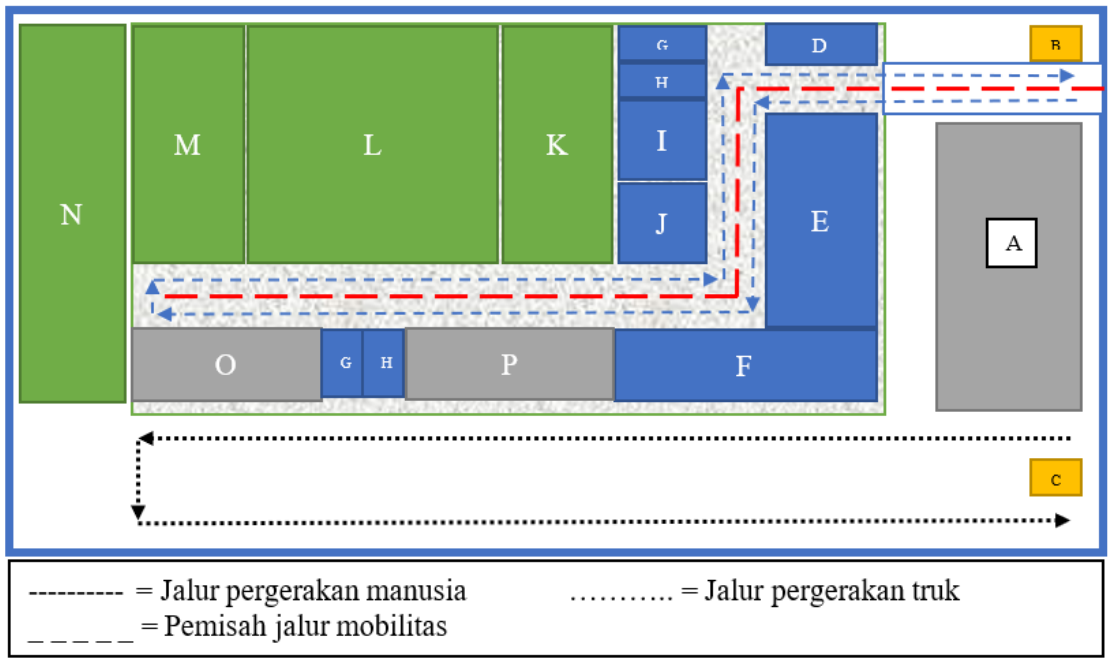

Gambar 12 Simulasi Pengaturan Mobilitas dalam Layout Pabrik Padat. Sumber : Hasil Olahan Penulis, 2021

\section{SIMPULAN}

Indonesia merupakah salah satu negara yang mengandalkan bidang industri riil termasuk industri padat karya dalam menopang perekonomian. Pada masa pandemi, industri padat karya termasuk bidang industri yang sangat terpukul karena episentrum baru yang muncul di kalangan pekerjanya. Sangat penting bagi bisnis untuk terus dapat melangsungkan proses produksi di masa pandemi, namun di sisi lain pekerja padat karya juga membutuhkan perlindungan maksimal akan keselamatan jiwanya. Dari hasil penelitian ini terdapat beberapa rekomendasi dalam penanggulangan Covid-19 di area industri padat karya, yaitu mulai dari Mitigasi Risiko Tinggi maupun Rendah. Pada Mitigasi Risiko Tinggi terdapat beberapa rekomendasi, yaitu perubahan layout produksi, instalasi partisi antar pekerja, membatasi kapasitas karyawan dalam menggunakan fasilitas kantor maupun didalam ruangan tertentu. Mitigasi Risiko Rendah yang dapat dilakukan diantaranya adalah pemberian sekat pada jalur sirkulasi di area industri, yaitu dengan membuat sebuah koridor.

Artikel ini diharapkan dapat memberikan solusi dan opsi bagi industri padat karya dalam upayanya tetap menjaga perlindungan pekerjanya dari penularan virus Covid-19, di mana hingga saat ini masih bermunculan kasus-kasus baru pada sektor ini. Sangat diharapkan adanya artikel yang meneliti lebih lanjut akan pengaruh dari desain mitigasi risiko ini, mengukur efektivitasnya dalam menanggulangi risiko penularan Covid-19 di area pabrik industri padat karya.

\section{DAFTAR PUSTAKA}

Cheshmehzangi, A. (2020). 10 Adaptive Measures for Public Places to face the COVID 19 Pandemic Outbreak. City \& Society, 32(2). https://doi.org/10.1111/ciso.12335

Dai, A. (2011). Drought under global warming: A review. Wiley Interdisciplinary Reviews: Climate Change, 2(1), 45-65. https://doi.org/10.1002/wcc.81

Deni, A., \& Riswanto, A. (2019). Analysis of Factors That Influence The Disclosure Of Enterprise Risk Management in SMEs. Jkbm (Jurnal Konsep Bisnis Dan Manajemen), 6(1),

1. 
https://doi.org/10.31289/jkbm.v6i1.2475

Harmen, H. (2018). Pengaruh Talent Management dan Knowledge Management Terhadap Kinerja Karyawan PT. Perkebunan Nusantara II (Survei Pada Kantor Direksi Tanjung Morawa). Jkbm (Jurnal Konsep Bisnis Dan Manajemen), 4(2). https://doi.org/10.31289/jkbm.v4i2.1587

Herman, R. (2014). Analisa Pengaruh Biaya Tenaga Kerja dan Output Terhadap Permintaan Tenaga Kerja pada Sub-Sektor Industri Padat Karya di Indonesia [Universitas Padjadjaran]. https://repository.unpad.ac.id/frontdoor/index/ index/year/2020/docId/3523

Kristyanto, R., Industri, J. T., \& Brawijaya, U. (2013). Analisis Risiko Operasional Pada Proses Produksi Gula Dengan Menggunakan Metode MultiAttribute Failure Mode Analysis (Mafma) ( Studi Kasus: Pg . Kebon Agung Malang ). Jurnal Rekayasa Dan Manajemen Sistem Industri, 3(3), 592-601.

Menteri Perindustrian Republik Indonesia. (2020). Pelaksanaan Operasional Pabrik Dalam Masa Kedaruratan Kesehatan Masyarakat Coronavirus Disease 2019. Surat Edaran Menteri Perindustrian, No. 4. http://jdih.kemenperin.go.id/site/baca_peratura $\mathrm{n} / 2634$

Menteri Tenaga Kerja dan Transmigrasi. (2014). Peraturan Menteri Tenaga Kerja dan Transmigrasi Republik Indonesia. Peraturan Menteri Tenaga Kerja Dan Transmigrasi, VII(8), 1-69.

https://indolabourdatabase.files.wordpress.com /2018/03/permenaker-no-8-tahun-2010tentang-apd.pdf

Neeltje van Doremalen, P., Infectious, (National Institute of Allergy and, Diseases), Trenton Bushmaker, B. S. N. I. of A. and, Diseases), \& Dylan H. Morris, M. P. (Princeton U. (2020). Aerosol and Surface Stability of SARS-CoV-2 as Compared with SARS-CoV-1. New England Journal of Medicine, 0-2.

Rana, S., \& Belokar, R. M. (2017). Quality Improvement Using FMEA: A Short Review. International Research Journal of Engineering and Technology, 4(6), 263-267. https://irjet.net/archives/V4/i6/IRJETV4I645.pdf

Russell \& Taylor. Operations Management. International Student Version. 2011.

Santoso, S. (2019). Risk and Social Economic Factor as a Management Risk Revealing (Vegetables Farmer Decision Making Study in Pujon Sub District Malang Regency ). International Journal of Science and Research 8(10), 35-49.

Santoso, S., \& Handayani, R. (2010). Pengembangan Struktur Ekonomi Jawa Timur pada Tahun 2002 dengan Menggunakan Linear Goal Programming. Jurnal Teknik Industri,3(2), 93103.

https://doi.org/10.22219/JTIUMM.Vol3.No2.93103

Simbolon, R., \& Santoso, S. (2021). Product and Service Quality Improvement In Manufacturing: A Study Of Optical Lens Manufacturing In Indonesia, Jurnal Media Ekonomi dan Manajemen, Vol. 36 (1)-2021, https://doi.org/10.24856/mem.v36i1.1726

Shebl, N. A., Franklin, B. D., \& Barber, N. (2012). Failure mode and effects analysis outputs: Are they valid? BMC Health Services Research, 12(1). https://doi.org/10.1186/1472-6963-12-150

Simsekler, M. C. E., Ward, J. R., \& Clarkson, P. J. (2018). Design for patient safety: a systems-based risk identification framework. Ergonomics, 61(8), 1046-1064.

https://doi.org/10.1080/00140139.2018.14372 24

Stamatis, D. H. (2003). Failure Mode and Effect Analysis: FMEA from Theory to Execution. ASQ Quality Press.

Sun, J., Zhu, A., Li, H., Zheng, K., Zhuang, Z., Chen, Z., Shi, Y., Zhang, Z., Chen, S. bei, Liu, X., Dai, J., Li, X., Huang, S., Huang, X., Luo, L., Wen, L., Zhuo, J., Li, Y., Wang, Y., ... Li, Y. min. (2020). Isolation of infectious SARS-CoV-2 from urine of a COVID-19 patient. Emerging Microbes and Infections, 9(1), 991-993.

https://doi.org/10.1080/22221751.2020.17601 44

Tsai, S. B., Zhou, J., Gao, Y., Wang, J., Li, G., Zheng, Y., Ren, P., \& Xu, W. (2017). Combining FMEA with DEMATEL models to solve production process problems. PLoS ONE, 12(8), 1-15. https://doi.org/10.1371/journal.pone.0183634

Wang, Y., Qiao, F., Zhou, F., \& Yuan, Y. (2020). Aerosol and Surface distribution of severe acute respiratory syndrome coronavirus 2 in Leishenshan Hospital in China. Indoor and Built Environment, 26(7). https://doi.org/10.1177/1420326X20942938

World Health Organization. (2014). Infection Prevention and Control of Epidemic-and pandemic-prone Acute Respiratory Infections in Health Care. The International Encyclopedia of Biological Anthropology, 1-2. https://doi.org/10.1002/9781118584538.ieba0 303

Yang, T., \& Hung, C. C. (2007). Multiple-attribute decision making methods for plant layout design problem. Robotics and Computer-Integrated Manufacturing, 23(1), 126-137. https://doi.org/10.1016/j.rcim.2005.12.002 